\title{
INCREASING INTEREST AND STUDENT LEARNING OUTCOMES BY USING COOPERATIVE LEARNING TYPE 'MAKE A MATCH'
}

\author{
Dian Pratiwi \\ Manajement Study Program, Muhammadiyah University of Pringsewu \\ dianpratiwi@stiemuh-pringsewu.ac.id
}

\begin{abstract}
The purpose of this research is improve the interest and learning outcomes of student grade XI Senior High School of Muhammadiyah Pringsewu on Verb and Noun material by using cooperative learning type "Make a Match". Data collection component obtained from the pre-test, post-test I and II, questionnaires, observations and interviews. The results showed thatthe application of cooperative learning model of "Make a Match" can increase student interest and learning outcomes XI Senior high school class Muhammadiyah Pringsewu on Verb and Noun material.
\end{abstract}

Keywords : Interest, Make a Match, material verb and noun, outcome learning.

\section{INTRODUCTION}

Learning can be interpreted as the result of memory, cognition, and metacognition that affect comprehension. This is what happens when a person is learning, and this condition is also common in everyday life, because learning is a natural process for everyone.According to Tomlinson (1998: 4), learning is normally considered to be a conscious process which consists of the committing to memory of information relevant to what happen learned. Whilst such direct learning of, for example , spelling rules, convention of greeting and vocabulary items can be useful to the language learner, it is arguable that much language learning consist of subconscious development of generalization about how the language is used and of skills which apply the these generalization to acts of communication. Hutchinson \& Waters (1987: 49) said that, learning is seen as a conscious process.

Nunan (2004: 6-7), learning is no longer seen simply as a process of habit formation. Learner and the cognitive processes they engage in as they are seen as fundamentally important to the learning process. Additionally, in recent years, learning

\section{Open Access}

Creation is distributed under the Creative Commons License Attribution-Share Alike 4.0 International

Published in http://ejournal.umpri.ac.id/index.php/smart/index

JurnalSMART : Journal of English Language Teaching and Applied Linguistics. 
as a social is increasing emphasized, and sociocultural theories are beginning to be drawn on in addition to (or even in preference to) cognitive theories.

One student learning success is influenced by the involvement of teachers in the learning activities. Teachers here play a role to guide students in their learning in school. Learning is said to be successful and qualified in whole or at least most of the learners engage actively, whether physical, mental or social in the learning process.

Teaching method is one of the ways that must be passed in teaching. The teacher teaching method is not good will affect the learning of students who are not good also. A poor teaching process can occur, for example teachers are poorly prepared and lack control of the subject matter so that the teacher presents them with unclear. Attitudes of teachers towards students as well as subjects those are not good to make students less against a lesson or teacher. As a result, the students are lazy to learn. The teacher should approach with students, so knowing the problems facing student learning, in addition, the teacher must dare to try teaching methods, so as to enhance the interest of students to learn.

Learning activities carried out by English teachers at SMA Muhammadiyah Pringsewu Lampung used more lecture and discussion methods. The frequent use of lecture and discussion methods makes students feel bored quickly. This feeling of boredom made students lazy when attending lessons. As a result of feeling lazy and bored, students often divert attention when learning by chatting. In this case the right method is needed to restore students' interest to study

In addition to the problems of the learning methods used by English teachers at SMA Muhammadiyah Pringsewu Lampung, the low interest of students in learning English is also influenced by the students' understanding of learning English. Based on the results of interviews with several students, English subjects are considered difficult and boring because of the many vocabularies that must be memorized, and must know the meaning of each vocabulary. The presumption that learning English is learning to memorize, this makes students lazy to learn. Though learning English is very fun because it is not only memorizing, but students must understand what is learned.

To resolve the problem of the learning, researcher used a cooperative learning model type "Make a Match" to increase interest and learning outcomes grade XI-1 at SMA Muhammadiyah in Pringsewu Lampung. Cooperative learning model type "Make 
a Match" to have a character that can provide space for students to interact with fellow students in or outside the classroom. The existence of interactions between students, are expected to reduce boredom students when studying in class as well as an interest in students to study also the higher.

Cooperative learning refers to a variety of teaching methods, where students work in one small group to help each other in learning the subject matter. Positive impact of cooperative learning, namely: developing relationships between groups, the growing awareness that the students need to learn to think, solve problems, and integrate and apply skills and knowledge them. Cooperative learning methods is already growing with various types, among others: Jigsaw, Team Games Tournament (TGT), "Make a Match" and many more.

According to Slavin (1994: 56-67), cooperative learning is a learning model, in which the students and work in heterogeneous learning teams. For collaborative learning to be effective, there should be both 'group goals' and 'individual accountability'. This means that the collaborative learning task must ensure that every group member has learnt something. Ideally, a collaborative learning task would allow for each member to be responsible for some concept necessary to complete the task. This implies that every group will learn their assigned concept and will be responsible for explaining/teaching this to other of the group.Cooperative learning is an approach to teaching that makes maximum use of cooperative activities involving pairs and small group of learner in the classroom. (Richards\& Teodore, 2001: 192).

The related research has already been conducted by Ade \&Sortha (2013) from State University of Medan. The title of her research is "Improving students' Vocabulary Achievement through 'Make a match' technique for Eight Grade Students of MTs Swasta Al-Badar Tanjungbalai". From this research, cooperative integrated 'Make a Match' technique can improve the students' achievement in vocabulary achievement. The result showed the mean of the second cycle is higher than the first cycle. Thus, by using 'Make a Match' technique to improvement the students' vocabulary achievement could be said if 'Make a Match' technique worked well which helped students to improve their vocabulary achievement and more interesting and enjoyable in vocabulary mastery. Then, the collaboration between Jigsaw and Make a Match was applyed by Nur et al (2017). They conducted the research to improveElementary students' activity. 
Furthermore, Arisanty and Riyah (2019) also conducted research by applying Make a Match to improve geography learning outcomes, and this technique had increased the student learning outcomes.

The implementation of "Make a Match" on students' learning interest is expected be able to improve students' learning outcomes, especially in verb and noun material. So, this research aimis increase the interest and learning outcomes of students grade XI at SMA Muhammadiyah Pringsewu Lampung in Verb and Noun material by using cooperative learning type "Make a Match".

\section{RESEARCH METHOD}

This research is classroom action research. The research involved collaboration and cooperation between the English teacher and the students. The researcher, the teacher and the students work together to apply "Make a Match" technique in teaching learning process.Action Research is research carried out by teacher in their context, in their classroom. Teachers identify a problem or an area they wish to improve and based on theory or experience or a hypothesis they think of an intervention. According to Burns (2009: 2), Action Research [AR] is part of a broad movement that has been going on in education generally for some time. It is related to the idea of 'reflective practice' and 'the teacher as a researcher'. Action Research involves taking a self-reflective, critical, and system approach to exploring your own teaching context.

"Make a match" is a way of learning by finding matching pairs of cards held, as in this study, there are two students who hold answer card and question card. Teaching and learning techniques are looking for partner (make a match) was developed by Lorna Curran in 1994. The advantage of this technique is the students find a partner while learning about a concept in a pleasant atmosphere. According to Agus Suprijono(2014: 94), the things that should be prepared in the learning with a make a match are cards. The cards consist of question and answered cards.

The participants are the students X1-1 grade students of SMA Muhammadiyah Pringsewu Lampung with the total students are 39. The research subjects wore only 35 students for the conduct of research because there are four students who do not follow the overall research activities. This research involved 2 kinds of data: quantitative and qualitative. The quantitative data were gained from test: pre-test and post-test, while 
qualitative data were collected from observation, questionnaire, and interview.The test was conducted to know the interest and students' learning. The test was administered before implementing the research (pre-test), and was also done after the treatment in cycle 1 and 2 (post-test). The pre-test consists of 20 multiple choices, while the post-test cycle I and II also use 20 multiple choices; the observations in this research are the observation sheets of the students' interest. This instrument is used to identify students' interest in students' activity in the classroom. These activities can be an activity to ask, discuss, give advice or question and answer questions. This instrument is used to know the students' interest in following the lesson; the questionnaire is used to directly identify students' interest. The questionere is filled directly by all students. The questionnaire contains 10 positive statements and 10 negative statements. The students must select the options already provided; the interview contains question related to students' interest in learning English, learning difficulties in the classroom and students' responses to the use of cooperative learning type "make a match". The questions consist to 5 questions.

\section{FINDING AND DISCUSSION}

This research aims to increase students' interest and learning outcomes. Increased students interest can be seen from changes in students' attitudes and students' involvement during the learning process. Changes in learning outcomes in the cognitive domain can be measured from the result of tests (pre-test, post-test I and post-test II). This research was conducted in two cycles, cycle I and cycle II.The research was conducted from October-November 2016, at SMA Muhammadiyah Pringsewu Lampung, with the subject of the research 35 students from 39 students. The research subject used only 35 students, because on the research implementation there were 4 students who did not follow the whole research activity. Students who cannot join because of some things; sick, follow the school activities, and do not enter without description. Then in the data analysis the result used are data from 35 students who follow the whole research activity. 


\section{The result of the research}

\section{Cycle I}

Cycle I started on 21-28 October 2016 as much as 3 times the meeting with a time allocation of $5 \times 45$ minutes. The first meeting learns about the meaning of Verb and Regular Verb (allocation of times 2x45 minutes). The second meeting learns about Irregular verb (allocation of times 1x45 minutes). And the third meeting with allocation of times 2x45 minutes learn to look for examples of words that includes in Regular and Irregular categories.

Table 1. The Result of pre-test

\begin{tabular}{cc}
\hline Explanation & Result \\
\hline Higher score & 75 \\
\hline Lowest score & 15 \\
\hline Mean score & 36,43 \\
\hline
\end{tabular}

Based on the pre-test result, the highest score is 75 , and the lowest score is 15 . The average score of students only reached 36.43 . The low score of students because students do not really understand the material being tested at the time of the pre-test.

Table 2.The result of post-test I

\begin{tabular}{lc}
\hline \multicolumn{1}{c}{ Information } & Post-test I \\
\hline The highest score & 75 \\
\hline The lowest score & 20 \\
\hline Mean score & 40.71 \\
\hline $\begin{array}{l}\text { Total students } \\
\text { reach KKM }\end{array}$ & 0 \\
\hline $\begin{array}{l}\text { Student. Students } \\
\text { morbidly reached }\end{array}$ & 35 \\
KKM & \\
\hline $\begin{array}{l}\text { \% Students } \\
\text { achieving KKM }\end{array}$ & 0 \\
\hline $\begin{array}{l}\text { \% Students } \\
\text { morbidly reach }\end{array}$ & 100 \\
KKM & \\
\hline
\end{tabular}

Based on the result of post-test I, it can be seen that no students reaches the score of KKM. Students who have not reached the KKM are 100\%, and students who reach $\mathrm{KKM}$ are still $0 \%$. The highest score only reaches 75 and the lowest score is 20 . The average students score is $40,71 \%$. The students' grade is still low because at the time of the post-test, students look less enthusiastic and less serious. 


\section{Cycle II}

Cycle II started on 9- 16 November 2016 as much as 3 times the meeting with a time allocation of $4 \times 45$ minutes. The first meeting learns about understanding of noun and kinds of noun (allocation of times 1x45 minutes). The second meeting, the students learn about Countable Noun and Uncountable Noun (allocation of times 2x45 minutes). And the third meeting with allocation of times $1 \times 45$ minutes used to review the material that has been learnt in the cycle II, then proceed with post-test II and fill the final questionnaire.

\section{Table 3. The result of post-test II}

\begin{tabular}{lc}
\hline \multicolumn{1}{c}{ Information } & $\begin{array}{c}\text { Post-test } \\
\text { II }\end{array}$ \\
\hline The highest score & 100 \\
\hline The lowest score & 55 \\
\hline Mean score & 82.71 \\
\hline $\begin{array}{l}\text { Total students } \\
\text { reach KKM }\end{array}$ & 28 \\
\hline $\begin{array}{l}\text { Student. Students } \\
\text { morbidly reached }\end{array}$ & 7 \\
$\begin{array}{l}\text { KKM } \\
\text { \% Students } \\
\text { achieving KKM }\end{array}$ & 80 \\
\hline $\begin{array}{l}\text { \% Students } \\
\text { morbidly reach }\end{array}$ & 20 \\
KKM & \\
\hline
\end{tabular}

Based on data, it can be seen that there has been an increase in scores from previous tests where the highest score obtained by the students is 100 and the lowest score is 55 . The numbers of students who reach the KKM are 28 students with a percentage of $80 \%$, while students who have not yet reached the KKM are 7 students with a percentage of $20 \%$. The average score of students has also reached $82,71 \%$.

\section{Discussion}

a) Learning outcomes

Students' learning outcomes in the form of post-test after cycle I and cycle II, indicatingthe increase in students' understanding of Verb and Noun material with the application of cooperative learning type "make a match". The increase can be seen from the result of post-test I and post-test II, the increase in both the average 
students score and percentage of students grade that reached the KKM. Overall, improvement of students' learning outcomes can be seen in the following chart:

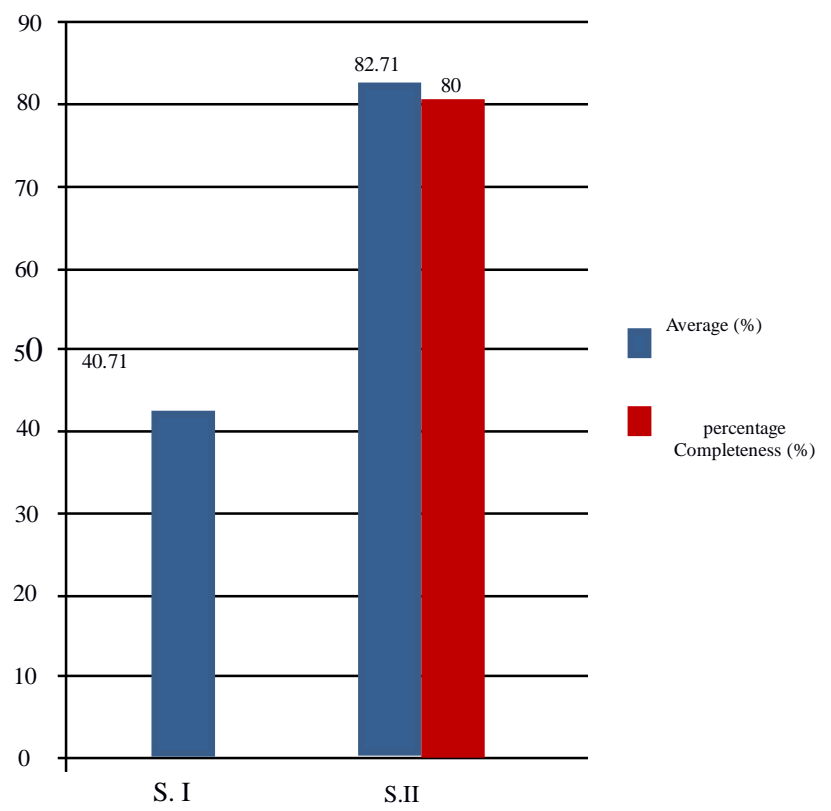

Chart 1.The development of student learning outcomes

Based on the chart, it is known that in the cycle I, the result of the average value of students in the post-test I only $40,71 \%$ with a percentage of completeness of $0 \%$. These results have not yet reached the target set by researcher. One of the reasons why KKM target percentage has not been achieved are one of them is when students are not seriously working on their work. This is indicated by the presence of some students who actually sleep in the class when post-test I going on; there are also some students who do not read the questions first, they immediately cross their answer; some students also said that some of the material that had been studied previously had been forgotten, so they had difficulty to answer the questions. In cycle II, the result of the average value of students in the post-test II reached $82,71 \%$ with the percentage of students completing the KKM being $80 \%$. These results still have not reached the target to be achieved in this study related to students learning outcomes of $85 \%$.

b) Student interests

The development of student interests is measured by a questionnaire and students observation sheet. The questionnaire was given twice, namely at the beginning of the cycle I and cycle II. An initial interest questionnaire was given to determine students' 
learning interest before using the "make a match" learning model. The final questionnaire was given to know the students' interest after using "make a match" learning model. From the result of the calculation of students' initial interest in the medium category a percentage of $14,29 \%$ was obtained, in the high category $80 \%$ and in the very high category $5,71 \%$.

The results of the final questionnaire showed an increase. It can be seen in the high category percentage of $80 \%$, while the very high category percentage of $14,28 \%$, but there are still 5, 72\% students with medium interest category. Data questionnaire can be seen in the following chart:

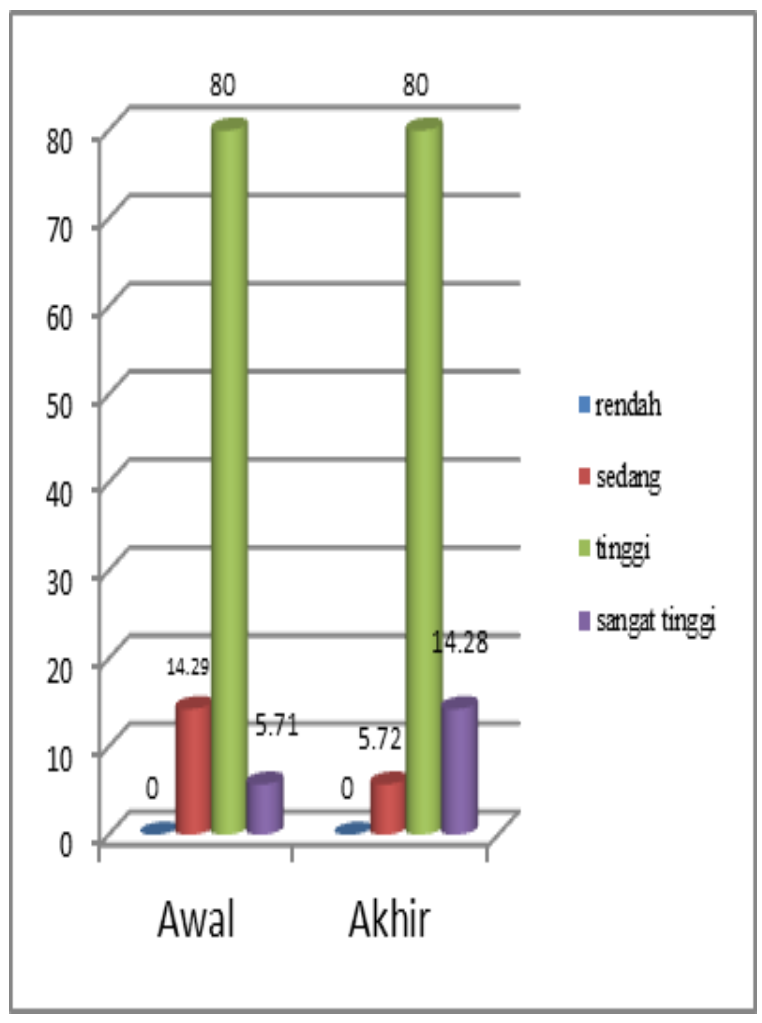

Chart2.Percentage of students' interest early and late

c) Interest and learning outcomes

The research aims to increase the interest and learning outcomes of students in class XI SMA Muhammadiyah Pringsewu on Verb and Noun materials. Based on the data that has been obtained from the research that has been done, there are many improvements related to the interest and learning outcomes students in class XI-1 on 
verb and noun material. The result of the interest and students learning outcomes can be seen in the following chart:

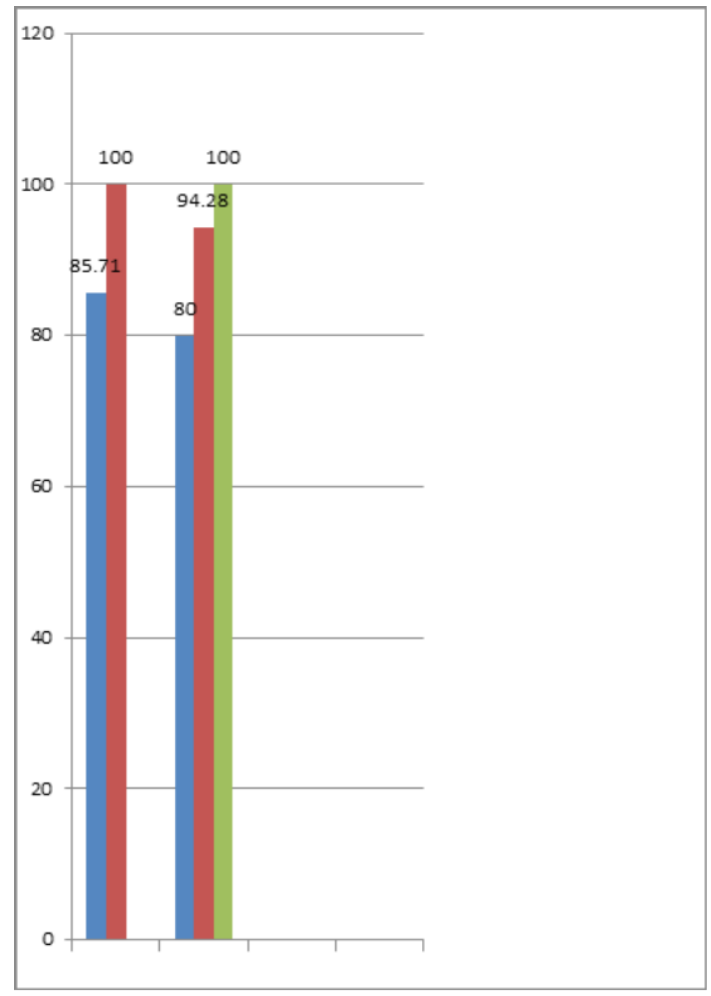

Chart 3.Final data of interest and student learning outcomes

Based on these chart, it can be seen that increasing students' interest is both seen in the result of the questionnaire and the observation of students' interest accompanied by increasing students learning outcomes. This can be said that increasing the students' learning interest can improve students' learning outcomes.

\section{CONCLUSIONS}

Based on the result of Classroom Action Research (CAR) and data obtained from the result of research conducted in two cycles, it can be concluded that the application cooperative learning type "make a match" can increase Interest and students' learning outcomes in the XI grade at SMA Muhammadiyah Pringsewu. It can be proved by the comparison between the students' score mean in the pre-test and the post-test in cycle 1, the post test in cycle 2. The first post-test result is higher than the pre-test result. The mean of students' score on the pre-test is 36.43 , increased to 40.71 in the post-test in 
cycle 1 . The second post-test result is higher than the first post-test result. The mean of students' score on the first post-test is 40.71 , it increases to be 82.71 . It shows that use of cooperative learning type "make a match" can increase interest and students learning outcomes

\section{REFERENCES}

Ade, Iriyani \& Sortha, Silitonga(2013).Improving Students' Vocabulary Achievement through "Make a Match" Method. REGISTER Journal. Vol 2 (4).

Agus, Suprijono. (2009). Cooperative Leaarning: Teori dan Aplikasi PAIKEM. Pustaka Pelajar: Yogyakarta

Arisanty, D and Riyah.(2019). Application of make a match model to improve geography learning outcomes. JOTSE.Vol 9(1), 32-40.

Burns, A. (2009). Doing Action Research in English Language Teaching: A Guide for Practitioners. New York: Routledge.

Hutchinson, T and Alan Waters.(1987). English for Specific Purposes.A Learningcentered Approach. New York. Cambridge University Press

Nunan, D. (2004). Task-based Language Teaching. Cambridge: Cambridge University Press.

Nur, Aini,WH., Suharno, Mintasih, I. (2007). The Use of Cooperative Learning of Jig Jaw type and Make a Match type to Improve students' activity. International Journal of Recent Engineering Science (IJRES). Vol 32, 2349-7157.

Richards, Jack C and Teodore S. Rodgers.(2001). Approaches and Methods in Language Teaching.Second Edition. New York: Cambridge University Press.

Slavin, Robert E. (1994).A Practical Guide to Cooperative Learning. John Hopkin University.

Tomlinson. (1998). Material Development in Language Teaching. United Kingdom: Cambridge University Press. 